\title{
Artistic entrepreneurship and the need for market orientation in the context of rising significance of the Creative Industries
}

\author{
Konrad Olesiewicz
}

Kozminski University

olesiewicz@gmail.com 


\begin{abstract}
Purpose: The purpose of this paper is to present a conceptual background and definitions helpful for further research of growth oriented artistic entrepreneurship. Creative industries are becoming increasingly important to the economy of developed countries. This fact is starting to affect the creative arts sector both as a source of creative and artistic workers, innovation and a potential source of higher economic contributions. A brief macro to micro analysis puts the phenomenon in a wider context. Analogies between academic and artistic work are drawn in order to allow the possibility of exploring what seems to be a similar process that had already happened in the education sector. In several aspects congruence between artistic and knowledge based work is presented. Additionally, the paper presents some initial data collected from a preliminary qualitative study of 4 in-depth, open-ended, semi-structured interviews with growth oriented artistic entrepreneurs and artists.
\end{abstract}

Findings: Literature and initial field studies seem to indicate that artistic and administrative, business-like, activities differ in terms of methods used. They also suggest that this may impact the work of artistic entrepreneurs and their willingness to further develop the venture. This is connected with the fact that many artists seem to operate in very specialized expert markets which can prove to be a challenge in a successful commercialization of their work.

Originality/value: The paper contributes to the development of a topic that has not been studied well, but might be of significance in the near future. Initial macro and micro analysis of the phenomenon of artistic entrepreneurship tries to take into account perspectives from several disciplines in order to contribute to the accumulation of, so far, very scarce knowledge on the topic.

Keywords: artistic entrepreneurship, artists, creative industries

Paper type: Conceptual and research paper

\title{
Introduction - significance, economic context, assumptions
}

According to DCMS ${ }^{1}$, as a result of restructuring and globalization, the "new economy" will put creativity at the forefront, and the creative industries at the core of occurring changes (DCMS, 2008). However bold this may sound, figures seem to justify the enthusiasm towards creative industries as a whole, and creativity as a mean of creating new and significant knowledge through innovation (Landry \& Bianchini, 1995). In years from 1999 to 2003 the growth of the creative sector in the EU was $12,3 \%$ higher than the growth of the whole economy (Comission, 2007). Additionally, in years 2000 and 2005 the volume of trade of goods produced by the creative sector, on average, rose by $8,7 \%$ per annum (UNCTAD, 2008). The government of Great Britain reported that in 2008 the contribution of creative industries amounted to 7,3\% of the gross domestic product (DCMS, 2008) and that, despite the financial crisis, the sector noted positive growth in comparison to rest of the economy.

Sigmund Bauman metaphorically stated that capitalism, or in this case the capitalist market mechanism, constantly searches for new lands to colonize (Bauman, 2010). Departing from this perspective and considering sustainable economic growth, one can expect that where all easily accessible "new lands" were already colonized it may become increasingly important to include and optimize the lands that were until now on the borders of economic interest.

\footnotetext{
${ }^{1}$ DCMS - UK's Department for Culture Media and Sport
} 
Scholars studying growth and various factors of production are unanimous that technological advancement and accompanying rise of effectiveness of work is responsible for sustainable economic growth. Various growth models, from Solow's (1956), through Romer and Mankiw's (1990) and Uzawa-Lucas's (Barro \& Sala-i-Martin, 1995) models define technological advancement as initially exogenous and later, gradually developed, and endogenized cause of increased productivity and in effect growth. Initially simplistic models became even more complex including new factors of production like human capital (Kawa, 2007). Recently factors that are even harder to conceptualize are taken into account. Examples might include social capital, with it generalized trust and willingness to participate (Putnam, 1993 ) or the size of personal networks, which may make access to certain resources easier (Bourdieu, 2011). It possible, in this perspective, that with the deepening of the understanding of creativity and its economic significance, it will become eventually endogenized and DCMS's claim will have merit.

Departing from economic growth, Schumepter studied the nature of business cycles where after periods of stability come more turbulent times often accompanied by technological revolutions and changes in way of production (Joseph A. Schumpeter, 1934/2002). On an abstract level this bears similarity to work of Kuhn, who studied the cycles of scientific revolutions and how knowledge is accumulated, from lack of a paradigm, through its verification and optimization towards its "crisis" where it no longer has explanatory power to accommodate new observations (Kuhn, 1962/2001); thus new tools for knowledge accumulation emerge. From the perspective of creativity, one can risk to say that scientific and artistic work carry much resemblance (Strzałecki, 2001) and as such they should bear similarities regarding its development and challenges. Drawing upon the depicted analogy, art can be portrayed as constant creation and development of esthetic trends or "schools" until they reach saturation reaching a certain "artistic paradigm" or including a particular "ism" (like Picasso's cubism) in the domain of general knowledge and accepted way of working with certain artistic and esthetic problems. Such convergence of economics, science, art and entrepreneurship can produce a new optic that could link them in a common context in order to draw from various more developed disciplines.

Trying to combine the functionalist and interpretative (Burrell \& Morgan, 1979), a more interconnected, socio-economic, evolutionary perspective is assumed stating that the structure has effect on the individuals but that also individuals are affecting the structure in an emergent way. To put it simply, taking economic individualism into account, it is believed that the economic order is emergent as unintentional effect of intentional action undertaken by individuals realizing their particular aims in a institutional context (Radzka, 2009). When considering the individual it is best to cite Schumpeter and his strong opinion on the fact that "[...] the economy does not grow to higher levels by itself" (Swedberg, 2006, p. 247) as he portrayed the entrepreneur as the main engine for development using the opportunities spawned by change and technological development. Schumpeter used a metaphor saying that the static economy is "like a frame of a painting" and that the "picture itself is yet to be painted", comparing an entrepreneur to a painter (Joseph Alois Schumpeter, 2003, p. 66).

In terms of artistic and scientific work it was clear that the artist and the scientist were the focal object of interest, but Schumpeter and his entrepreneur were one of the inspirations that put emphasis on the human factor, innovation and creativity, in relation the economy. This seems to imply that the entrepreneur and the artist should be the desired unit of analysis for understanding the micro-foundations of growth in the creative industries. 


\section{Creative Industries - a brief introduction and why artists matter}

In the era of globalization and accelerating product cycles (Kozminski, 2005) many countries are unable to successfully compete in terms of production and manufacturing capabilities against such countries like e.g. China. In 1997 Tony Blair's government launched a program called "Creative Britain". This program aimed to prepare UK's economy to switch to a "new model", based on creativity, in order to create a competitive advantage (DCMS, 2007). The case of Great Britain is considered paradigmatic (Cunningham, 2003) in development of the concept of creative sector that aimed to "move creative industries from the margin of economic thought to its mainstream" (DCMS, 2008, p. 6). As of today these industries note the highest growth in the UK. This seems to be significant not only because it results in obtaining a resource which is valuable, scarce and hard to imitate, along the login of the VRIN model (Eisenhardt \& Martin, 2000, p. 1105), but also because it allowed to allocate capital to those segments of the economy characterized by higher marginal productivity resulting in economic growth.

DCMS defines creative industries as those housing sectors like for example, advertising, architecture, arts, performing arts, crafts, computer games and others (DCMS, 2009). Other international organizations operate on their own definitions of creative industries (UNCTAD, 2008; WIPO, 2003) sometimes called the copyright industries. Nevertheless they all, at least partially, can be defined as those sectors that "supply goods and services that we broadly associate with cultural, artistic, or simply entertainment value" (Caves, 2000, p. 1). It is often common to differentiate between cultural industries, that have to do more with art, and creative industries that are more applicable in their nature (Hesmondhalgh \& Pratt, 2005). Nevertheless various authors suggest that all these activities create a certain integral sector where "human creativity is the ultimate resource" (Florida, 2002, p. xiii) and its main input (DCMS, 2008).

It is often said that the distinction should be made between those sectors open to mass production and distribution and those that are focused on crafts and creating "prototypes" like performing, visual arts and cultural heritage. However a consensus exists that the creative arts sector lies at the core of creative industries, also in historical terms. Despite their relatively small, yet still significant, economic contribution, the creative arts sector, and its schooling, as source of skills and attitudes, is considered to be important to the development of creative industries as a whole (Pawłowski, 2009). There seem to be al least two strong points of connection. Firstly, conducted studies (Oakley et al., 2008) have shown that people devoted to the arts sector:

- Have attitudes and skills that are conductive to innovation;

- Artistic labor impacts on innovation in the way it is organized;

- Artistic labor impacts on innovation through the widespread culturalisation of activities.

The second point of departure is that comparing artists as a whole in historic terms they can be viewed as "early" versions of a considerable population of knowledge workers. According to many scholars knowledge work is characterized by its auto-telic character (Hunter, Jemielniak, \& Postula, 2010) which translates to issues connected with instrinc and extrinsic motivation (Amabile et. al., 1994). This is characterized by a higher need of selfexpression and its rising significance in post-materialistic societies. This fact is also connected to creativity more efficiently conceived in a less standardized environment (Kondo, 2000) and then transferred to mass distribution media. 
Analogies on this level were found in academic entrepreneurship (Jain, George, \& Maltarich, 2009) and even highly aesthetical work of computer programmers in IT companies (Case \& Piñeiro, 2006; Jemielniak, 2010) which seem to experience similar conflicts and dilemmas as artists, especially those involved in commercialization of their works. The degree of those is of course somewhat different, but in essence the mechanisms seem to be similar in terms of artistic work, as one of the first broadly acceptable forms of creative work which now seems to be more significant than ever before. By being so, it coined many definitions and stereotypes that constitute an intuitional environment (Eikhof \& Haunschild, 2006) passed on to their more applicable "cousins" like architecture or design and many others (Abbing, 2002; Caves, 2000). Concluding, a better understanding of growth oriented artistic entrepreneurs can not only contribute to understanding any talent-based entrepreneurship and commercialization of creativity, but also can supply insight into the challenges of managing creative workers.

\section{Entrepreneurship and artistic entrepreneurship - point of departure and the sample}

Entrepreneurship is a widely debated topic amongst academics and there are many approaches and perspectives. One of them, opportunity recognition and innovation seems to be especially important (Shane \& Venkataraman, 2000). This in combination that the entrepreneur faces genuine uncertainty (Knight, 1921/2009) to get vision across, makes scholars reconsider the exclusively utilitarian approach to venture creation (Joseph A. Schumpeter, 1934/2002). Sometimes an entrepreneur is even called "a kind of an artist" (Kozminski \& Jemielniak, 2008, p. 392). This seems to be valid in the light of such definition of entrepreneurship as one given by Casson: "entrepreneur believes he is right, while everyone else is wrong. Thus the essence of entrepreneurship is being different - being different because one has a different perception of the situation." (2003, p. 16).

If we would switch entrepreneurship to art from Timmons definition we would receive the following (1989, p. 49):

"Art is a human, creative act that builds something of value from practically nothing. It is the pursuit of opportunity regardless of the resources, or lack of resources, at hand. It requires vision and the passion to lead others in the pursuit of that vision. It also requires a willingness to take a calculated risk."

Suffice it to say entrepreneurship is largely associated with innovation and introduction of novelty (Kirzner, 2009; Schumpeter, 1942/2010) which is directly connected with creativity. Various scholars seem to agree that innovation is the commercialization of creativity (Henry \& Walker, 1991) that is why they are often intermixed. Although some argue that creativity is not an essential perquisite for innovation (Amabile et. al., 1996) majority of high growth enterprises thrive on introducing a new product or service (Cumming, 1998). This is significant as growth oriented enterprises are high contributors to economic development (Cieślik, 2008) and innovation is often the characteristic that differentiates small business owners from entrepreneurs (Carland, Hoy, Boulton, \& Carland, 1984; Cieslik, 2006)

The fact of successfully commercializing a creative idea is the core of topics like academic or technological entrepreneurship (Jain, et al., 2009) as it is at the core of artistic entrepreneurship. Creativity can be defined as transgression of existing boundaries, seeing more and the ability to find patterns where others see none (Kozielecki, 1987). This is the task 
that artists have been trained to since time immemorial. Nevertheless, introducing a new product to a commercial market is another task which often can spawn a conflict of having to efficiently implement an idea which is being connived in a chaotic, experimental way. In this case the true added value seems to come from the merging of "fire and water" and in order to do so growth oriented artistic entrepreneurs need to have both, vision and organizational capacities.

Such growth oriented artistic entrepreneurs have to expand beyond single person studios and face the realities of running a company which can serve as a vessel of self realization and delivering their ideas to a broader audience. With this come new challenges like fixed costs of running a business, need of organizing work and actively exploring opportunities for improving their work. In this perspective and school of thought this study a growth oriented entrepreneur is defined as "a person being an artist managing its business employing several people and that the primary activity of the business if directly connected with the artistic skills known and practiced by the owner".

Examples may include actors running their own theaters, independent musician running their own production houses, artistic jewelry or fashion designers running their own shops and production lines. In order to rule out respondents that might be biased by economic factors and in order to have greater homogeneity thought the sample only accomplished and leading (in their respective fields) artistic entrepreneur are taken into consideration. This also results in having data from those individuals who managed to successfully merge artistic creation with commercialization of their work.

\section{Creativity - qualitative problem solving}

Ecker describes the process of artistic creation as qualitative problem solving. In his view the creation of a piece of work is a series of many problems and their controlled resolution analogously to the scientific process. Citing Dewey, he depicts a dealing with a single problem that constitutes a part of the whole as: (i) feeling the problem; (ii) localizing and defining the problem; (iii) suggesting a possible solution; (iv) development basing on the suggestion; (v) further experimentation working towards accepting or rejecting the solution (1963). Dewey remarks that: "The artist has his problem and thinks as he works. [...] the scientific worker operates with symbols, words and mathematical signs. The artist does his thinking in the very qualitative media he works in [...]" (1934, p. 16). Nevertheless, putting emphasis on the iterative, experimental process he stated that the artists and scientist have very much in common in regards to their work. Ecker concluded that in order to develop a piece of work a series of decision has to be made and that so far there are no instant recipes for producing a scientific nor artistic breakthrough. It is a similar case with business, where after that much research and practice it is impossible to cite a golden rule for successful innovative venture. Generalizations and forms of standardization, like good practices and recipes, being quantitative in their nature cannot fully grasp qualitative action like innovation or creativity.

A similar view is shared by Caves, the father of term "creative industries", who notes that: "[...] solving artistic problems resembles scientific inquiry: what new discovery will produce the most value and what research strategy will bring it to realization?" (2000, p. 22). Similarly to Dewey he adds that the artistic process seems to be less formalized than the scientific one. 


\section{"Artistic paradigm" - and its implications}

Drawing upon the observed analogies between artistic and scientific work, one can try to understand the way they both develop and what are its practical implications. In his study, Kuhn observed that when dealing with mature scientific disciplines books are no longer the most effective way of communicating new ideas in contrast to scientific papers. It is due to the fact that with the creation of paradigms that "carry" in them a certain amount of knowledge, the scientific community does not have to start their discussions from basic sources and can draw from generalizations and developed theories (Kuhn, 1962/2001). This of course assumes that all the specialists (scientists for this matter) in a given field are familiar with the previously generated knowledge. At the same time Kuhn suggests that a layman does not have a real chance of following the scientific progress by familiarizing himself with the current academic reports written by the scholars. He makes a very suggestive statement that, for example in mathematics, the reports of advancements in the field, were probably not possible to understand by an "averagely educated person" since the ancient times.

With regards to the above it is worth considering if something very similar doesn't occur with the most developed forms of art such as for example painting or similar. In order to do so it would seem to be significant to introduce the definition of culture following CzarniawskaJoerges as the "medium of life" and though the help of symbols it allows us to see and understand the world and that due to its network nature it orders perception (1991). In his book, Cultural Industries, Hesmondhalgh defines culture as a „system of meaning”, through which the social order is being communicated and reproduced (2005). Therefore the cultural industry is involved in producing social meaning in the form of texts and symbols and are a kind of alphabet in themselves. Traveling down this path of thought this would mean that most probably the "averagely educated recipient" is not familiar with the appropriate set of symbols and "letters" enabling him to understand (decode) and thus appreciate the novel concept presented by an artist that worked within, or tried to contradict, a certain artistic paradigm. That would suggest that many of the works of art, and definitely most of the avantgarde pieces, are in fact targeted at other artists or the very few that have the knowledge to actually understand them, not to mention being entertained by them.

Such a claim seems to be backed up the research done by Getzels and Csikszentmihalyi who ran experiments by showing a certain amount of artwork to a judge panel. The judge

panel consisted of laymen and art teachers. It turned out that where the latter mostly valued the general esthetics and the level of technical proficiency and realism, the experts favored the pieces that tried to creatively tackle with some kind of artistic problem (1976).

\section{Conflict \#1 - Art vs. Commercialization and the artistic product}

Drawing upon the artistic paradigm it could be observed, as Caves stated, that serious artists want to develop and affect their discipline the same way their academic counterparts do (2000, p. 23). And as one of the respondents noted:

ArtTe01: "Many artists fail to recognize that art is also a form of entertainment and create works that are not appealing to the majority of the audience (theater)."

and on the other hand some agreed that: 
ArtMa01: "Art is art when you introduce a kind of new quality... you know... something has not been done before, something that is new and has some certain aspects to it. Any other way is just copying existing ideas."

ArtTe01: "Well of course art should have some novel elements but it's very hard to find balance between creativity and artistic freedom and doing a good show that will captivate the public."

The ever rising complexity, something Kuhn called "professionalization", of works of art resulted in the fact that "the evaluation of a work of art is difficult and may be undertaken only by the experts" (Kostera \& Śliwa, 2010, p. 205). This further results in creating a class of intermediaries called the gatekeepers (Caves, 2000), acting as translator for the abstract symbolic of art, who decide what is to be presented to the public and what kind of pieces will have a chance to be added to various distribution channels. This further separates the artist from the end consumer.

When trying to compare an entrepreneur and an artist it comes to mind that the targets and methods of evaluation of the work of both, vary. For example the "traditional" entrepreneur is being, in general, validated by the free market, which is usually broader and more "impartial" and quantifiable. When an entrepreneur introduces some kind of product to the market it is being evaluated either positively or negatively by consumers, this process can be captured in a quasi-objective amount of money earned or lost. The core of the presented conflict is that, in the case of an artistic entrepreneur, his work is validated by two evaluation mechanisms. The market evaluation and the expert (market) evaluation. In order to have artistic merit the product often has to be complex and innovative which may stand in contrast to the needs of a successful market validation. While doing business, a rational (in economic terms) thing to do for the artistic entrepreneur is that he probably should focus on the market validation. But it is often he will not do so because of the creative need of contributing to the discipline and the artistic legitimization the artistic community grants him.

ArtMo01: "Of course the community is important for me. It is very important to keep in touch with $<<$ bohemian circle $>>$. They are the ones that can truly understand my work and I don't feel like a crazy woman (laughter). These meetings are a source of inspiration I wouldn't be able to work without".

Yet it is very often that the community in general may not approve of the business orientation of some endeavors.

ArtMo01: "In Poland everybody thinks that art should be closed in a museum behind a glass wall as something sacred. It is very hard for some to understand that art without the people to appreciate it is just dead. So what if I can inspire a handful of people? We should be able to inspire a crowd!"

Since many analogies between scientific and artistic work has been established, it is possible to draw from research done on academic entrepreneurs (Jain, et al., 2009) to try to sum up the differences and similarities in outputs or the of artist, academics and an entrepreneur. 
Table 1 - Artist, Entrepreneur, Academic, similarities and differences regarding outputs

\begin{tabular}{l|l|l|l}
\hline & \multicolumn{1}{|c|}{ Artist } & \multicolumn{1}{c|}{ Entrepreneur } & \multicolumn{1}{c}{ Academic } \\
\hline \multirow{2}{*}{ Outputs } & Works & Products \\
& Peer recognition/status & Profit & $\begin{array}{l}\text { Papers } \\
\text { Peer recognition/status }\end{array}$ \\
\hline
\end{tabular}

source: own research and based on (Jain, et al., 2009)

In its essence, from a socio-economic perspective, the conflict between art and commerce can be conceptualized as a simple two dimensional continuum narrowing down to the potential market for a product. On one axis lies the complexity and relevance of the products in terms of advancement of artistic merit and on the other the shift from material and monetary to status and peer recognition rewards. This is shown on the diagram below:

Diagram 1 - Conceptual division of markets from smaller, elite and "highbrow" to popular and possible emphasis on reward from profits (more extrinct) to non-monetary (more instrinct).

source: own conceptualization

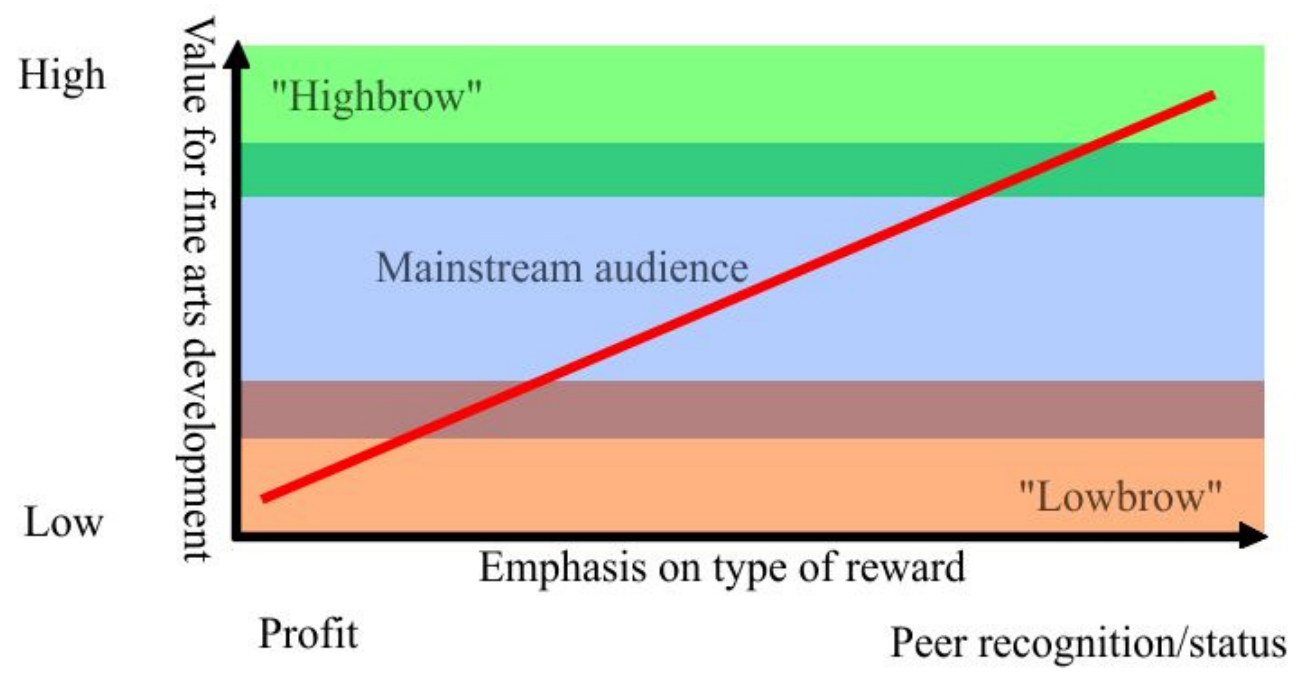

The terms of artistic merits are evaluated by the gatekeepers as this is almost impossible to determine "objectively" and is very relative. Though not all that is "complex" necessarily has to have high artistic value (in the context of artistic problems solved). Much like entrepreneurs, many artists were in a state of conflict with elites of their trade, quite similarly like many visionary scholars who tried to bring science to "the masses" or transgress disciplines, were considered "un-rigorous" or even charlatans. Elaborating on the $\mathrm{x}$ axis that point to the emphasis of type of reward this is interesting as theory of labour cannot always be applied to all types of labour and that artists' behaviours tend not to reflect the economic conditions. Cultural economics explains this behaviour as an intrinsic motivation which is comparable with pecuniary external incentives (Abbing, 2002; Frey, 1997). Instinct motivation will be elaborated in the next section but for reference one can see Throsby (1994), who created a model of artists (and scientists) work preference in economic terms. 
We can only imagine how unproductive the world would be if every student obtaining a higher degree would want to become a scientist. What is important and relevant to practice is that in essence the schooling system, at least in Poland, is designed to train "highbrow" artists without putting emphasis on practical skills. This thesis seem to be supported both by literature and initial field studies. A report on Polish schooling system state that "artistic schooling is a base for the development of many sectors of $<<$ free time economy $>$ and its state translates to the tempo of growth of the entire economy", yet students seem to be detached from the market which results in high rates of unemployment in this sector (Pawłowski, 2009). In short, the market for complex artistic goods is small and is greatly oversaturated. This is consistent with finding of Abbing (2002) who in his book tried to answer the question "why are artists poor?".

ArtMo2: "In art school we mainly talked about fine art and the classes were very spiritual and inspiring but no emphasis was put on the technical side of creating a piece of work. I had to learn most of what I know by myself, and it took me a few years since graduating to notice that; apart from thinking one has to do."

ArtMa01: "It's incredible when you think of it. Everybody seems to be concentrated on the $<<$ concept $>>$ instead of finishing the actual work. And the ones that get finished won't probably last more than 10 years. Comparing to some paintings that survived for hundreds of years I consider this a step back..."

Studies showed that with having high aspirations in the art world, coupled with lack of "hard skills" to express those ideas can lead to frustration and withdrawal (Popek, 2008) and the inability to have either profit, satisfaction or peer recognition. This is a challenge that countries, more advanced on the path of including the creative industries in the mainstream economics, have already started dealing with. One of many examples can be a program aiming to introduce entrepreneurship to art students that was launched in UK (Brown, 2004).

\section{Conflict \#2 - Artism vs. Managerism and the nature of work}

The second plane of potential conflicts faced by artistic entrepreneurs seems to lie in the nature of artistic and entrepreneurial work itself. As the venture develops and grows the main emphasis shifts from direct creative work on the technological level to managing and organizing of work. This seems to be a critical moment for many artistic entrepreneurs and seems to be much deeper than the usual "fear of delegation". In its essence when starting a venture the entrepreneur has some kind of talent and manual abilities that are closely related to his chosen field of development. Studies show that knowledge work and the motivation to do it is often better understood when assuming the Huzingian Homo Ludens, rather than the rational Homo Oeconomicus (Hunter, et al., 2010) perspective. This means that the more enjoyable his trade for the entrepreneur is the less likely he might be to want to let it go and focus on developing the venture. Various studies focused on the playful nature of certain types of knowledge professions and reported that it is a crucial part of motivation (Jemielniak, 2008) as self-expression and self-actualization is a very important, apart from profit, gain and is becoming even more salient in post materialistic societies (Kondo, 2000).

Amabile et. al. (1994) claims that "the stereotype of extrinsicly motivated businessman and instrincly motivated scientist or $<<$ starving artist $>>$ may have its source in a psychological truth". Furthermore she suggests that curiosity and need for self-development may be more significant for people performing creative tasks in contrast to those who are leaders or are 
more conventional. As the common denominator for this paper is innovation it seems apparent it will, to some point stand in line with many theories of creativity (Strzałecki, 2001) and seems to confirm the hubristic nature of creators (Kozielecki, 1987) either artistic or entreprenual. As creativity is not binary, the question lies in the degree of the phenomena.

This again spawns two challenges for the motivation for venture growth. Firstly this means that an artist who was able to invest a tremendous amount of time to build his skill to the point he is able to open a successful business is most probably instrinctly motivated and will experience this conflict to some degree. What is "dangerous", from the perspective of further venture development, is that the administrative work is often considered to be an obstacle or tedious duty.

ArtMo01: "Before we start let me tell you that I am very frustrated with the current situation. Instead of doing something useful I have to deal with loads of unimportant stuff like renting this studio for some kind of a fashion show. It's still money and I have to pay the rent for the shop but there is no one who could do that for me."

ArtMo2: "Sure I have assistants but I am the only one who can bind the artistic vision with the realities of we can actually do (pause). Sometimes I feel I'm doing neither."

The individualistic nature of artists' work can be troublesome when it comes to delegation and ability to lead instead of directing. Definitely, relatively low levels of managerial education may also be an issue.

The second challenge is that creative, qualitative, work requires different skills and mind patterns than business, more quantitative work. This periods of "switching" can take a long time and the "time lag" between these moments is time lost.

ArtTe01: "Sure I can do both, I have the knowledge, but it is very frustrating when I have to manage something and work on the script in a short period of time. I somehow have to let go many things in order to go on with the plot and again I have to concentrate on the finest detail when something needs to be done (organized)."

ArtMo2: "When I have some good ideas I do not want to distract myself and my people sometimes chase me down the corridor when they need some stuff signed (laughter). It's not that I don't like that, it's just that I know that once I get distracted with all the complexities of who and when all I will be able to do is staring at a blank page in front of me for the rest of the day."

This is also why, according to Bain (2005), over $78 \%$ of non-entrepreneur artists that work part-time choose to have the non-art job to be a menial one not requiring their attention or concentration, in order to work on their art at home. She also claims that having two attention consuming jobs (day job and art job) is a significant challenge for artist's identity integrity (p. 14). Is this regards, on the metaphorical level, the (in)famous saying of "Art for art's sake" is not only a manifesto but also a description of a community being instrinsicly motivated to develop their field and skill. This also captures the auto-telic nature of artists work which is now becoming more common in other knowledge based industries.

Various studies have shown that artists are able to sacrifice their own well being and their family life in order to pursue their calling (Eikhof \& Haunschild, 2006) which may prove a challenge for artistic entrepreneur who not only needs to find a blend between market and 
expert product but also between developing their art (the very reason they started the business) and their company. In fact some seem to be very conscious about this fact:

ArtMa01: "I could have left for London or Paris, to be where the really exciting and avant-garde things are happening, but I decided to stay and work here."

ArtMo01: 'It's very nice when I have some visitors from the East in my shop. They say that what I do here is incredible. That I try to present my works and works of other artists to Poles. The truth is that most of people here do not know what is really good or bad but I think it will change over time".

It means that at some point the artistic entrepreneur may have to make the decision either to relocate, to a place where the expert market for art is bigger, and develop their skill and art to a maximum possible level or to stay and try to educate, thus broaden, the domestic market. This is a very important distinction, because when they decide they will sacrifice a part of their artistic career in order to develop a vehicle for self-realization, in the form of a venture, and broadening of own artistic opportunities locally. To live "pure art" some of the artists can also join the fine arts academia, but positions are very limited and many of them will withdraw and settle for part-time menial jobs.

Drawing on further analogies from academic entrepreneurship a summary of differences and similarities regarding the process of the work of an artist, entrepreneur and an academic can be presented.

Table 2 - Artist, Entrepreneur, Academic, similarities and differences regarding process

\begin{tabular}{l|l|l|l}
\hline & \multicolumn{1}{|c|}{ Artist } & \multicolumn{1}{c}{ Entrepreneur } & \multicolumn{1}{c}{ Academic } \\
\hline \multirow{3}{*}{ Process } & \multicolumn{1}{c}{ Experimentation } & Focus & Experimentation \\
& Ehort term goals & Long term goals \\
& Long term goals & Individual \\
\hline
\end{tabular}

source: own research and based on (Jain, et al., 2009)

\section{Conclusions and further research}

While striving in converting creativity into innovation, growth oriented artistic entrepreneur face many challenges to successfully develop their venture in order to both: sustain self-development and earning profits. In fact it seems very tricky to find the right configuration, trying to combine "fire and water" in terms of discovering a prosperous blend of product complexity and target and organization of the venture. Returning to evolutionary perspective on economics this is the search for the right "fit" (Siggelkow, 2002) in the environment where the past definition of "fit" is not compatible with occurring changes. Another important factor is the institutional environments that seems to be adapting to new realities slowly. This may be of significance in the perspective that it often remains a source of artistic validity and creative hub for exchanging ideas. Nevertheless citing Fillis and Rentschler one can say that: "Artists such as Pablo Picasso and Salvador Dali were never really tamed by the artistic establishment of mainstream thinking. They used their unique creative abilities to create demand for their work." (2005, p. 280).

Moreover, high-growth oriented artistic enterprises not only are able to produce added value to the GDP but also might be responsible for various beneficial spillover effects. One of 
them is the activation and creating employment opportunities for artists that would not launch their own enterprises and would hold menial part-time jobs not fulfilling their potential and not capitalizing on resources already invested in their education. The other, seems to be an important role in broadening the market for artistic goods through their local work and educating the consumer. Both contribute to the base of the creative industries that are already known to be a sector of rising significance in knowledge economies.

One may risk saying that the depicted conflicts are present in most enterprises in creative industries. As some of them are more utilitarian from day one (services like photography, architecture, advertisement etc.) it is only a question of the degree of the observable phenomena. Working on a, somewhat, polarized and thus easier to study sample like more auto-telic, independent, artistic entrepreneurs, which is the case in this and further studies, gives the opportunity to observe facts with a greater clarity and a narrower grey zone.

It would be beneficial to investigate the topic further in order to develop a body of knowledge that might be helpful as a base in launching educational programs or raising awareness of the topic for policymakers or artistic entrepreneurs willing to learn.

Apart from broadening the sample and going beyond the initial study there are still questions waiting to be answered. One of them could be how do the artistic entrepreneurs design their products so that they keep the balance between broad market appeal and artistic integrity and value. Also the motives of creating a growth oriented artistic enterprises vs. developing individual carriers should be studied. It is already known that running an enterprise impacts the work of the artistic entrepreneur and might prove a challenge to his identity integrity. Jain et. al (2009) or Pratt et.al (2006) studied how the professional identity of academic entrepreneurs and medical staff developed in terms of identity management. They identified several mechanism like delegation, buffering or splinting of various tasks in order to integrate various identities or keep a dominant, salient, one. This perspective could shed some new light on the phenomenon of growth oriented artistic entrepreneurship and provide explanatory value.

\section{References}

Abbing, H. (2002) Why are artists poor?: The exceptional economy of the arts.

Amabile, T.M., R. Conti, H. Coon, J. Lazenby, \& M. Herron. (1996) "Assessing the Work Environment for Creativity." The Academy of Management Journal 39(5): 1154-1184.

Amabile, T. M., K.G. Hill, B.A. Hennessey, \& E.M. Tighe. (1994) "The Work Preference Inventory: assessing intrinsic and extrinsic motivational orientations." Journal of personality and social psychology 66(5): 950-967.

Bain, A. (2005) "Constructing an artistic identity." Work, Employment \& Society 19(1): 2546.

Barro, R. J., \& X. Sala-i-Martin. (1995) Economic growth. New York: McGraw-Hill.

Bauman, Z. (2010) Żyjąc w czasie pożyczonym. Kraków: Wydawnictwo Literackie.

Bourdieu, P. (2011) "Cultural theory: an anthology." In Cultural Theory: An Anthology, eds. I. Szeman \& T. Kaposy. Chichester, Malden, MA: Wiley-Blackwell.

Brown, R. (2004) Performing arts entrepreneurship. Lancaster: Palatine.

Burrell, G., \& G. Morgan. (1979) Sociological paradigms and organisational analysis: elements of the sociology of corporate life. London: Heinemann. 
Carland, J. W., F. Hoy, W.R. Boulton, \& J.A.C. Carland. (1984) "Differentiating Entrepreneurs from Small Business Owners: A Conceptualization." The Academy of Management Review 9(2): 354-359.

Case, P., \& E. Piñeiro. (2006) "Aesthetics, performativity and resistance in the narratives of a computer programming community." Human Relations 59(6): 753-782.

Casson, M. (2003) The entrepreneur an economic theory.

Caves, R. E. (2000) Creative industries: contracts between art and commerce. Cambridge, Mass.; London: Harvard University Press.

Cieślik, J. (2008) "Przedsiębiorstwo dynamiczne." Master of Business Administration 6(95).

Cieślik, J. (2006) Przedsiębiorczość dla ambitnych: jak uruchomić własny biznes. Warszawa: Wydawnictwa Akademickie i Profesjonalne.

Comission, E. (2007) Communication for a European agenda for culture in a globalizing world. Brussels: European Commission.

Cumming, B. (1998) "Innovation overview and future challenges." European Journal of Innovation 1(1): 21-29.

Cunningham, S. D. (2003) "The evolving Creative Industries: From original assumptions to contemporary interpretations." from http://eprints.qut.edu.au/4391/1/4391_1.pdf

Czarniawska-Joerges, B. (1991) "Culture is the medium of life." In Reframing organizational culture, eds. P.J. Frost \& L.F. Moore, 285-297. Newbury Park.

DCMS. (2009) Investing in creative industries?: A guide for local authorities. London: LGA.

DCMS. (2008) Creative Britain - New Talents for the New Economy. Intellectual Property. London.

DCMS. (2007) Staying Ahead: The Economic Performance of the UK Creative Industries. London.

Dewey, J. (1934) Art as experience. New York: Minton, Balch \& Company.

Ecker, D.W. (1963) "The Artistic Process as Qualitative Problem Solving." The Journal of Aesthetics and Art Criticism 21(3): 283-290.

Eikhof, D.R., \& A. Haunschild. (2006) "Lifestyle Meets Market: Bohemian Entrepreneurs in Creative Industries." Creativity and Innovation Management 15(3): 234-241.

Eisenhardt, K.M., \& J.A. Martin. (2000) „Dynamic capabilities: What are they? “ Strategic Management Journal 21(10-11): 1105-1121.

Fillis, I., \& R. Rentschler. (2005) "Using creativity to achieve an entrepreneurial future for arts marketing." International Journal of Nonprofit and Voluntary Sector Marketing 10(4): 275-287.

Florida, R. (2002) The Rise of the creative class: And how it's transforming work, leisure, community and everyday life. New York: Basic Books.

Frey, B.S. (1997) Not just for the money: An economic theory of personal motivation. Cheltenham, UK; Brookfield, Vt.: Edward Elgar Pub.

Getzels, J.W., \& M. Csikszentmihalyi. (1976) The creative vision: A longitudinal study of problem finding in art. New York: Wiley.

Henry, J., \& D. Walker. (1991) Managing innovation. London, Newbury Park : Sage Publications, in association with the Open University.

Hesmondhalgh, D., \& A.C. Pratt. (2005) "Cultural industries and cultural policy." International Journal of Cultural Policy 11: 1-13.

Hunter, C., D. Jemielniak, \& A. Postula. (2010) "Temporal and spatial shifts within playful work." Journal of Organizational Change Management Journal of Organizational Change Management 23(1): 87-102.

Jain, S., G. George, \& M. Maltarich. (2009) "Academics or entrepreneurs? Investigating role identity modification of university scientists involved in commercialization activity." Research Policy 38(6): 922-935. 
Jemielniak, D. (2010) "Software engineers or artists? Programmers' identity choices." Tamara Journal for Critical Organization Inquiry 7(1): 20-36.

Jemielniak, D. (2008) Praca oparta na wiedzy: praca $w$ przedsiebiorstwach wiedzy na przykladzie organizacji high-tech. Warszawa: Wydawnictwa Akademickie i Profesjonalne: Akademia Leona Koźminskiego.

Kawa, P. (2007) „Kapitał ludzki jako czynnik wzrostu gospodarczego w ujęciu nowych teorii wzrostu." In Zarzadzanie kapitatem ludzkim w gospodarce, ed. D. Kopycińska, 7-17. Szczecin: Katedra Mikroekonomii Uniwersytetu Szczecińskiego.

Kirzner, I. (2009) „The alert and creative entrepreneur: a clarification.” Small Business Economics 32(2): 145-152.

Knight, F.H. (1921/2009) Risk uncertainity and profit. Whitefish, MT: Kessinger Publishing.

Kondo, Y. (2000) "Innovation versus standardization." The TQM Magazine 12(1): 6-10.

Kostera, M., \& M. Śliwa. (2010) Zarzadzanie w XXI wieku. Warszawa: Wydawnictwa Akademickie i Profesjonalne.

Kozielecki, J. (1987) Koncepcja transgresyjna człowieka: analiza psychologiczna. Warszawa: Państwowe Wydawn. Nauk.

Koźminski, A.K., \& D. Jemielniak. (2008) Zarządzanie od podstaw: podręcznik akademicki. Warszawa: Wydawnictwa Akademickie i Profesjonalne.

Koźmiński, A.K. (2005). Zarzązanie $w$ warunkach niepewności: podręcznik dla zaawansowanych. Warszawa: Wydaw. Naukowe PWN.

Kuhn, T.S. (1962/2001) Struktura rewolucji naukowych. Warszawa: Fundacja Aletheia.

Landry, C., \& F. Bianchini. (1995) The creative city. London: Demos.

Mankiw, N.G., D. Romer, \& D.N. Weil. (1990) A contribution to the empirics of economic growth. Cambridge, MA.

Oakley, K., B. Sperry, A.C. Pratt, H. Bakhshi, National Endowment for Science T., \& the, A. (2008) "The art of innovation how fine arts graduates contribute to innovation." from http://www.nesta.org.uk/publications/reports/assets/features/the_art_of_innovation

Pawłowski, K. (2009) Raport o stanie kultury $w$ obszarze szkolnictwa artystycznego. Warszawa.

Popek, S. (2008) Kwestionariusz twórczego zachowania KAHN. Lublin.

Pratt, M., K. Rockmann, \& J. Kaufmann. (2006) "Constructing professional identity: The role of work and identity learning cycles in the customization of identity among medical residents." Academy of Management Journal 49(2).

Putnam, R.D. (1993) "The prosperous community: Social capital and public life." In The American Prospect 4.

Radzka, B. (2009) „Nowy i stary instytucjonalizm. Spotkanie socjologii i ekonomii.” Master of Business Administration 2(97).

Schumpeter, J. A. (2003) "The theory of economic development." In Eph Alois Schumpeter: entrepreneurship, style and vision, ed. J. G. Backhaus. Boston: Kluwer Academic Pub.

Schumpeter, J.A. (1942/2010) Capitalism, socialism and democracy. London: Routledge.

Schumpeter, J.A. (1934/2002) The theory of economic development: An inquiry into profits, capital, credit, interest, and the business cycle. New Brunswick: Transaction Publ.

Shane, S., \& S. Venkataraman. (2000) "The Promise of Enterpreneurship as a Field of Research." Academy of Management Review 25(1): 217-226.

Siggelkow, N. (2002) "Evolution toward Fit." Administrative Science Quarterly 47(1): 125159.

Solow, R.M. (1956) "A Contribution to the Theory of Economic Growth." The Quarterly Journal of Economics 70(1), 65-94.

Strzałecki, A. (2001) „Twórcza przedsiębiorczość. Próba analizy psychologicznej.” Prakseologia 141, 417-440. 
Swedberg, R. (2006) "The cultural entrepreneur and the creative industries: Beginning in Vienna." Journal of Cultural Economics.

Throsby, D. (1994) "A Work-Preference Model of Artists Behavior." In Cultural Economics and Cultural Policie, eds. A. Peacock \& I. Rizzo, 69-80. Dordrecht: Kluwer.

Timmons, J.A. (1989) The entrepreneurial mind. Andover, Mass.: Brick House Pub. Co.

UNCTAD. (2008) Creative economy report 2008. New York: United Nations.

WIPO. (2003) Guide on surveying the economic contribution of the copyright-based industries. Geneva: World Intellectual Property Organization. 